Article

\title{
Saccharomyces cerevisiae Dehydrated Culture Modulates Fecal Microbiota and Improves Innate Immunity of Adult Dogs
}

\author{
Karine de Melo Santos ${ }^{1}$, Larissa Wünsche Risolia ${ }^{1}$, Mariana Fragoso Rentas ${ }^{1}$, Andressa Rodrigues Amaral ${ }^{2} \mathbb{D}$, \\ Roberta Bueno Ayres Rodrigues ${ }^{1}$, Maria Isabel Gonzalez Urrego ${ }^{1}$, Thiago Henrique Annibale Vendramini ${ }^{1}$, \\ Ricardo Vieira Ventura ${ }^{1}$, Júlio César de Carvalho Balieiro ${ }^{1}$, Cristina de Oliveira Massoco ${ }^{1}$ (D), \\ João Paulo Fernandes Santos ${ }^{1}$, Cristiana Fonseca Ferreira Pontieri ${ }^{3}$ and Marcio Antonio Brunetto ${ }^{1,2, *}$ \\ 1 Pet Nutrology Research Center, Nutrition and Production Department, School of Veterinary Medicine and \\ Animal Science, University of São Paulo, Pirassununga 13635-900, SP, Brazil; \\ kdemelosantos@yahoo.com.br (K.d.M.S.); larissa.risolia@usp.br (L.W.R.); mariana.rentas@usp.br (M.F.R.); \\ roberta_barodrigues@hotmail.com (R.B.A.R.); migu@usp.br (M.I.G.U.); thiago.vendramini@usp.br (T.H.A.V.); \\ rvventura@usp.br (R.V.V.); balieiro@usp.br (J.C.d.C.B.); cmassoco@gmail.com (C.d.O.M.); \\ joao_paulo@zootecnista.com.br (J.P.F.S.) \\ 2 Veterinary Nutrology Service, Veterinary Teaching Hospital, School of Veterinary Medicine and \\ Animal Science, University of São Paulo, Cidade Universitária, Sao Paulo 05508-270, SP, Brazil; \\ andressa.rodrigues.amaral@usp.br \\ 3 Nutrition Development Center, Grandfood Industria e Comercio LTDA (Premier Pet), \\ Dourado 13590-000, SP, Brazil; cristiana@premierpet.com.br \\ check for
} updates

Citation: Santos, K.d.M.; Risolia, L.W.; Rentas, M.F.; Amaral, A.R.; Rodrigues, R.B.A.; Urrego, M.I.G.; Vendramini, T.H.A.; Ventura, R.V.; Balieiro, J.C.d.C.; Massoco, C.d.O.; et al. Saccharomyces cerevisiae Dehydrated Culture Modulates Fecal Microbiota and Improves Innate Immunity of Adult Dogs.

Fermentation 2022, 8, 2.

https: / /doi.org/10.3390/

fermentation 8010002

Academic Editor: Ronnie G. Willaert

Received: 22 November 2021 Accepted: 13 December 2021 Published: 23 December 2021

Publisher's Note: MDPI stays neutral with regard to jurisdictional claims in published maps and institutional affiliations.

Copyright: (C) 2021 by the authors. Licensee MDPI, Basel, Switzerland. This article is an open access article distributed under the terms and conditions of the Creative Commons Attribution (CC BY) license (https:// creativecommons.org/licenses/by/ $4.0 /)$.
Abstract: Saccharomyces cerevisiae yeast culture can be dehydrated, and it has a potential prebiotic effect. This study evaluated the effects of supplementing increasing levels of dehydrated yeast culture (DYC) of Saccharomyces cerevisiae (Original XPC ${ }^{\mathrm{TM}}$, Diamond V, Cedar Rapids, IA, USA) on fecal microbiota, nutrient digestibility, and fermentative and immunological parameters of healthy adult dogs. Eighteen adult male and female dogs with a mean body weight of $15.8 \pm 7.37 \mathrm{~kg}$ were randomly assigned to three experimental treatments: CD (control diet), DYC 0.3 (control diet with $0.3 \%$ DYC) and DYC 0.6 (control diet with $0.6 \%$ DYC). After 21 days of acclimation, fecal samples were collected for analysis of nutrient digestibility, microbiota and fecal fermentation products. On the last day, the blood samples were collected for the analysis of immunological parameters. The microbiome profile was assessed by the Illumina sequencing method, which allowed identifying the population of each bacterial phylum and genus. The statistical analyses were performed using the SAS software and the Tukey test for multiple comparison $(p<0.05)$. Our results suggest that the addition of DYC increased the percentage of the phyla Actinobacteria and Firmicutes $(p=0.0048$ and $p<0.0001$, respectively) and reduced that of the phylum Fusobacteria $(p=0.0008)$. Regardless of the inclusion level, the yeast addition promoted reduction of the genera Allobaculum and Fusobacterium ( $p=0.0265$ and $p=0.0006$, respectively) and increased $(p=0.0059)$ that of the genus Clostridium. At the highest prebiotic inclusion level (DYC 0.6), an increase $(p=0.0052)$ in the genus Collinsella and decrease $(p=0.0003)$ in Prevotella were observed. Besides that, the inclusion of the additive improved the apparent digestibility of the crude fiber and decreased the digestibility of crude protein, nitrogen-free extract and metabolizable energy $(p<0.05)$. There were no significant changes in the production of volatile organic compounds. However, an increase in propionate production was observed $(p=0.05)$. In addition, the inclusion of yeast resulted in an increased phagocytosis index in both treatments $(p=0.01)$. The addition of 0.3 and $0.6 \%$ DYC to the diet of dogs wase able to modulate the proportions of some phyla and genera in healthy dogs, in addition to yielding changes in nutrient digestibility, fermentative products and immunity in healthy adult dogs, indicating that this additive can modulate fecal microbiota and be included in dog nutrition.

Keywords: bacteria; beta-glucan; fermentation; illumina; mannan oligosaccharides; prebiotic 


\section{Introduction}

Prebiotics are substrates that are selectively used by host microorganisms and promote health benefits [1]. By modulating the intestinal microbiota, prebiotics can alter the host physiology and improve the fight against innumerable metabolic and immune infections and diseases, such as obesity, diabetes, and inflammatory bowel disease [2]. Yeasts are an example of prebiotics used in nutrition, such as Saccharomyces cerevisiae.

Structurally, the yeast cell wall of $S$. cerevisiae is composed of two fractions: one formed by beta-1,3/1,6-glucans and chitin, and another comprising mannoproteins partially formed by mannan oligosaccharides (MOS) [3]. S. cerevisiae can be dehydrated and is used as the commercial product Original XPC ${ }^{\mathrm{TM}}$ (Diamond V, Cedar Rapids, IA, USA). Its final composition includes MOS, beta-glucans, nucleotides, organic acids, polyphenols, amino acids, vitamins and minerals.

The MOS present in the Saccharomyces cerevisae cell wall is able to increase lactobacilli populations [4] and fecal bifidobacterial populations [5], which are considered beneficial bacteria to the host, and it appears to preserve the integrity of the gut absorption surface [6]. Another component, the beta-glucan, can selectively stimulate the growth of lactobacilli populations in a rat model [7], which also suggests a prebiotic activity [8].

Some studies have evaluated the supplementation of prebiotics with similar compositions of $S$. cerevisiae for modulation of fermentative products in dogs and obtained lower concentrations of phenols and indoles [9], reduced fecal ammonia excretion [10], and an increase in short chain fatty acids (SCFA) [11].

Regarding immunological parameters, supplementation with MOS present in the yeast cell wall can induce an increase in white cell blood concentrations, stimulating the immune response against pathogens [12], in addition to reducing inflammatory activity and improving innate immunity $[11,13]$.

Considering these potential benefits, the aim of this experiment was to evaluate the effect of a food enriched with increasing levels of a commercial product called Original $\mathrm{XPC}^{\mathrm{TM}}$ (Diamond V, Cedar Rapids, IA, USA) (OXPC) composed of dehydrated yeast culture on fecal microbiota, nutrient digestibility, and fermentative and immunological parameters in healthy adult dogs.

\section{Materials and Methods}

\subsection{Ethics}

All experimental procedures were approved by the Ethics Research Committee for Animal Welfare of the School of Veterinary Medicine and Animal Science, University of São Paulo (protocol number 9148270415).

\subsection{Animals}

The experiment was carried out at the Nutritional Development Center and Bromatology Laboratory of the Premier Pet company, located in Dourado, São Paulo, Brazil. Eighteen adult male and female dogs, with a mean weight of $15.8 \pm 7.37 \mathrm{~kg}$ and mean age of $3.3 \pm 1.58$ years, were included in this investigation (Table 1 ). The health status was confirmed prior to the beginning of the experiment. During the experiment, the dogs were housed individually in kennels with dimensions of $2.0 \times 5.60 \mathrm{~m}$ and solarium of $2.0 \times 4.90 \mathrm{~m}$.

\subsection{Experimental Design}

The animals were randomly assigned to one of three experimental treatments, resulting in 6 replicates per treatment. The whole experiment last 25 days, which included an acclimation period of 14 days for diet adaptation; after this period, total fecal samples were collected for analysis of nutrient digestibility every day for a week (7 days). On the next 3 days, feces were collected immediately after defecation with sterile gloves for fecal $\mathrm{pH}$, fecal fermentation products, and microbiota analysis. On the last day, the blood samples were collected for analysis of immunological parameters. 
Table 1. Descriptive information of the animals included in the study.

\begin{tabular}{cccccc}
\hline Animal & Diet & Sex & Breed & Weight (Kg) & Age (Years) \\
\hline Animal 1 & DC & Male & Whippet & 11.6 & 1.5 \\
Animal 2 & DC & Female & English Setter & 24.4 & 1.7 \\
Animal 3 & DC & Female & Cocker Spaniel & 10.5 & 6.0 \\
Animal 4 & DC & Male & Beagle & 12.0 & 5.0 \\
Animal 5 & DC & Female & Beagle & 12.8 & 5.0 \\
Animal 6 & DC & Male & Golden Retriever & 29.0 & 3.3 \\
Animal 7 & OXPC 0.3 & Male & Beagle & 12.2 & 4.0 \\
Animal 8 & OXPC 0.3 & Female & Beagle & 10.4 & 4.0 \\
Animal 9 & OXPC 0.3 & Female & Whippet & 9.1 & 1.2 \\
Animal 10 & OXPC 0.3 & Female & English Bulldog & 12.6 & 2.6 \\
Animal 11 & OXPC 0.3 & Male & West Highland & 8.4 & 1.1 \\
Animal 12 & OXPC 0.3 & Male & Wabrado Terrier & 30.4 & 4.2 \\
Animal 13 & OXPC 0.6 & Male & Beagle & 14.5 & 5.7 \\
Animal 14 & OXPC 0.6 & Female & Beagle & 7.8 & 1.5 \\
Animal 15 & OXPC 0.6 & Male & French Bulldog & 15.2 & 2.4 \\
Animal 16 & OXPC 0.6 & Male & English Setter & 26.9 & 1.6 \\
Animal 17 & OXPC 0.6 & Male & Beagle & 11.4 & 4.0 \\
Animal 18 & OXPC 0.6 & Female & Golden Retriever & 25.0 & 4.5 \\
\hline
\end{tabular}

\subsection{Diets}

A control diet was formulated to meet the requirements of AAFCO [14] for adult dogs under maintenance, and the prebiotic was included in different concentrations. The additive used in this study was Original XPC ${ }^{\mathrm{TM}}$ (Diamond V, Cedar Rapids, Iowa, USA) (OXPC), composed of dehydrated yeast culture of S. cerevisiae, with approximately $11.50 \%$ moisture, $14.90 \%$ crude protein, $1.30 \%$ fat, $25.20 \%$ crude fiber, and $8.50 \%$ ash. The OXPC is produced through the fermentation of selected liquids and cereal grains and raw ingredients with S. cerevisiae. After this process, the entire culture medium is dried without destroying the yeast factors, B-vitamins, and other nutritional fermentation products to form the final product.

Experimental treatments included increasing levels of the additive, as follows: DC (control diet without OXPC), OXPC 0.3 (control diet with 0.3\% OXPC), and OXPC 0.6 (control diet with $0.6 \%$ OXPC). All diets were isonutritive and formulated with the same ingredients, differing only by the addition and concentration of OXPC, which was proportionally compensated by starch between diets (Table 2). Diets were extruded at the Pet Unit of Premier Pet, Dourado-SP (Brazil), and all ingredients were obtained from a single batch in order to avoid variability among treatments.

All animals were fed sufficient amounts of calories according to the National Research Council's energy requirement [15] for the maintenance of adult dogs, calculated as $95 \mathrm{kcal} \times(\mathrm{BW}){ }^{0.75}$ per day, with water offered ad libitum. The daily total amount of the food was divided into two equal portions, offered at 07:00 a.m. and 03:30 p.m. The feeders were removed $30 \mathrm{~min}$ after offering the diets. Consumption and food leftovers were measured and recorded throughout the experiment. 
Table 2. Ingredient and chemical composition of the experimental diets with and without the additive Original XPC ${ }^{\mathrm{TM}}(\mathrm{OXPC})$.

\begin{tabular}{|c|c|c|c|}
\hline \multirow{2}{*}{ Item } & \multicolumn{3}{|c|}{ Diets $^{1}$} \\
\hline & DC & OXPC 0.3 & OXPC 0.6 \\
\hline \multicolumn{4}{|l|}{ Ingredients (\%) } \\
\hline Starch & 1.00 & 0.70 & 0.40 \\
\hline Dehydrated yeast culture & - & 0.30 & 0.60 \\
\hline Corn grain & 20.91 & 20.91 & 20.91 \\
\hline Poultry viscera meal & 36.00 & 36.00 & 36.00 \\
\hline Broken rice & 30.00 & 30.00 & 30.00 \\
\hline Poultry fat & 8.20 & 8.20 & 8.20 \\
\hline Liquid palatability enhancers & 2.00 & 2.00 & 2.00 \\
\hline Powdered palatability enhancers & 0.50 & 0.50 & 0.50 \\
\hline Potassium chloride & 0.43 & 0.43 & 0.43 \\
\hline Common salt & 0.30 & 0.30 & 0.30 \\
\hline Premix mineral/vitamin ${ }^{2}$ & 0.52 & 0.52 & 0.52 \\
\hline Antifungal & 0.10 & 0.10 & 0.10 \\
\hline Antioxidant & 0.04 & 0.04 & 0.04 \\
\hline \multicolumn{4}{|l|}{ Chemical composition (\% of dry matter) } \\
\hline Ash & 6.65 & 5.92 & 6.09 \\
\hline Crude protein & 35.66 & 31.25 & 33.37 \\
\hline Fat & 15.63 & 16.38 & 14.36 \\
\hline Nitrogen-free extract ${ }^{3}$ & 35.35 & 39.09 & 39.58 \\
\hline Crude fiber & 6.71 & 7.36 & 6.59 \\
\hline Gross energy (kcal/g) & 5.23 & 5.22 & 5.14 \\
\hline
\end{tabular}

${ }^{1}$ DC (control diet), OXPC 0.3 (control diet with 0.3\% OXPC) and OXPC 0.6 (control diet with 0.6\% OXPC); ${ }^{2}$ Addition per kilogram of product: Iron $100 \mathrm{mg}$, Copper $10 \mathrm{mg}$, Manganese $10 \mathrm{mg}$, Zinc $150 \mathrm{mg}$, Iodine $2 \mathrm{mg}$, Selenium $0.3 \mathrm{mg}$, Vitamin A 18000IU, Vitamin D 1200IU, Vitamin E 200IU, Thiamine 6 mg, Riboflavin $10 \mathrm{mg}$, Pantothenic Acid $40 \mathrm{mg}$, Niacin $60 \mathrm{mg}$, Pyridoxine $6 \mathrm{mg}$, Folic Acid $0.30 \mathrm{mg}$, Vitamin B12 $0.1 \mathrm{mg}$, and Choline $2000 \mathrm{mg} ;{ }^{3}$ Nitrogen-free extract was calculated by the formula NFE $=100-($ Moisture + crude protein + fat + crude fiber + ash).

\subsection{Determination of the Coefficients of Apparent Digestibility of Nutrients}

The apparent digestibility coefficients (ADC) of the nutrients were determined by the total fecal collection method, according to AAFCO [14] recommendations. Individual food consumption was recorded daily, as well as the quantities offered and rejected. Feces were collected within a $24 \mathrm{~h}$ period for 7 days, subsequently weighed and conditioned in individual plastic bags, previously identified, closed, and stored in a freezer $\left(-15^{\circ} \mathrm{C}\right)$ for further analysis. At the end of the collection period, they were thawed and homogenized, forming a single sample per animal (feces pool). The content of dry matter (DM), crude protein $(\mathrm{CP})$, ethereal extract in acid hydrolysis, a.k.a. fat (EEAH), ashes, and crude fiber (CF) from food and feces were analyzed according to the methodology described by AOAC [16]. All analyses were conducted in duplicate and repeated when the coefficient of variation was greater than $5 \%$.

Nitrogen-free extract (NFE) was calculated by the difference between DM and the sum of $\mathrm{CP}, \mathrm{EEAH}, \mathrm{CF}$, and ashes. The gross energy (GE) of food and feces was determined on a calorimetric pump (1281, Parr Instrument Company, Moline, IL, USA). Based on the results obtained in the laboratory, ADC of DM, organic matter (OM), CP, EEAH, CF, and NFE of the diets were calculated. These calculations were performed with the following formula: CDC of the nutrient $(\%)=$ [ingested nutrient $(\mathrm{g})-$ excreted nutrient $(\mathrm{g})] /$ (ingested nutrient $(\mathrm{g}))] \times 100$.

\subsection{Determination of Fecal Score, Fecal $\mathrm{pH}$, and Ammoniacal Nitrogen}

The fecal score was evaluated according to grading scores from 0 to 5, of which $0=$ liquid stools; 1 = pasty and shapeless stools; $2=$ soft, malformed stools that assume the shape of the collection container; 3 = soft, formed, and moist stools that mark the floor; 
$4=$ well-formed and consistent stools that do not mark the floor; $5=$ well-formed, hard, and dry stools. Values between 3 and 4 were considered as ideal fecal score [17].

For determination of fecal $\mathrm{pH}$, a $2 \mathrm{~g}$ sample of feces was separated and diluted in $18 \mathrm{~mL}$ of distilled water within $30 \mathrm{~min}$ after defecation. Determination was carried out with a digital benchtop pH meter (Digimed, DM-20, São Paulo, SP, Brazil), according to the methodology adapted from Walter et al. [18]. For quantification of fecal ammoniacal nitrogen, stool samples were collected within $30 \mathrm{~min}$ after defecation. The sampling process, as well as the distillation, were performed according to Sá et al. [19].

\subsection{Evaluation of Volatile Organic Compounds in Feces}

Fresh feces were collected from the animals within $30 \mathrm{~min}$ after defecation and were quickly homogenized; $0.5 \mathrm{~g}$ of sample was placed in a sealed $20 \mathrm{~mL}$ glass vial with a leakproof metal cap and double-sided silicone/Teflon. Samples were stored and maintained at $-20^{\circ} \mathrm{C}$. The samples were evaluated by gas chromatography coupled to mass spectrometry (GC-MSD) (Agilent Technologies, Santa Clara, CA, USA) using an Agilent 7890 A gas chromatograph (CG) and an Agilent 5975C mass sorting detector (MSD), according to an adapted methodology $[20,21]$. The NIST mass spectra library of 2008 was used to identify the compounds detected.

\subsection{Determination of Short-Chain (SCFA) and Short Branched Chain Fatty Acids (SBCFA) and Lactic Acid in Feces}

Stool samples were collected within $30 \mathrm{~min}$ after defecation. Subsequently, they were homogenized and weighed for the quantification of SCFA and SBCFA. Three grams of feces were acidified with $9 \mathrm{~mL}$ of $16 \%$ formic acid in a $15 \mathrm{~mL}$ falcon tube. The determination of the short and short branched chain fatty acids was performed by gas chromatography (Shimadzu Corporation, Kyoto, Japan) according to Erwin et al. [22].

Lactic acid was measured according to the methodology described by Pryce et al. [23], by the spectrophotometry method at $565 \mathrm{~nm}$ (500 to $570 \mathrm{~nm}$ ). After collection, the feces were homogenized and mixed with $9 \mathrm{~mL}$ of distilled water $(1: 3 \mathrm{v} / \mathrm{v})$.

\subsection{Determination of Biogenic Amines}

Five grams of fresh stool were collected in duplicate within $30 \mathrm{~min}$ after defecation and stored in $7 \mathrm{~mL}$ of $5 \%$ trichloroacetic acid and refrigerated. Subsequently, the samples were centrifuged at $10,000 \times g$ for $20 \mathrm{~min}$ at $4{ }^{\circ} \mathrm{C}$, and the supernatant was filtered on qualitative filter paper. The residue was extracted two more times using $7 \mathrm{~mL}$ and $6 \mathrm{~mL}$ of $5 \%$ trichloroacetic acid. The supernatants were combined for further determination of the biogenic amines. The determination and separation of the biogenic amines were performed by high-performance liquid chromatography by reverse phase column ion pairing and subsequently quantified by fluorimetry after post-column derivation with second ophthalaldehyde [24]. The amines were identified by comparing the retention time of the peaks found in the samples with those of the amines of the standard solution, according to the methodology described by Gomes et al. [25].

\subsection{Determination of Fecal Bacteria Concentration by Illumina Sequencing Technology}

After a 7-day digestibility period, fecal samples were immediately and aseptically collected for 3 days for microbiota determination. The samples did not have contact with any other surface besides sterile gloves. The DNA extraction was performed using the Mobio Power Soil kit (MO BIO Laboratories, Carlsbad, CA, USA) according to the methodology described by McInnes et al. [26]. After extraction, the DNA concentration was quantified using a Qubit ${ }^{\circledR}$ 2.0 Fluorometer (Life Technologies, Grand Island, NY, USA).

Amplifications of the $16 \mathrm{~S}$ rRNA gene were generated using a Fluidigm Access matrix (Fluidigm Corporation, South San Francisco, CA, USA) in combination with a Roche High Fidelity Fast Start Kit (Roche, Indianapolis, IA, USA). For this step, primers 515F (5'-GTGCCAGCMGCCGCGGTAA-3') and 806R (5'-GGACTACHVGGGTWTCTAAT-3') 
291 bp-fragment of the V4 region were used [27]. After this, Fluidigm primer specific forward (CS1 tag) and inverse (CS2 tag) were added according to the Fluidigm protocol. To confirm the quality of the regions and the sizes of the amplicons, the fragment analyzer (Advanced Analytics, Ames, IA, USA) was used.

A pool of DNA was generated by combining equimolar amounts of the amplified fragments from each sample. The pooled samples were selected by gel size from $2 \%$ E-gel agarose (Life Technologies, Grand Island, New York, NY, USA) and extracted using Qiagen gel purification kit (Qiagen, Valencia, CA, USA). To confirm the appropriate profile and average size, the sorted and cleaned clustered products were run on an Agilent Bioanalyzer.

The characterization of the microbial community through the Illumina sequencing was performed on a MiSeq using V3 reagents (Illumina Inc., San Diego, CA, USA) at the W.M. Keck Center for Biotechnology at the University of Illinois. Fluidigm tags were removed using FASTX-Toolkit (version 0.0.13); to process the resulting sequence data, QIIME 1.8.1 was used according to Caporaso et al. [28]. The sequence data were imported from demultiplexed fastq files, and we filtered out low-quality sequencing reads considering a quality score threshold of 25. After that, the sequences were grouped into operational taxonomic units (OTUs) using OTU open reference and were compared against the reference database OTU Greengenes 13_8 using a 97\% similarity threshold.

An even sampling depth of sequences per sample was used for assessing alpha and beta diversity measures. A total of 917,433 reads were obtained, with an average of 50,436 reads (range $=17,666-93,602$ ) per sample. Rarefaction curves based on observed species, Chao1, and phylogenetic distance (PD) whole tree measures plateaued, suggesting enough sequencing depth. The dataset was rarified to 16,300 reads for analysis of diversity and species richness. Principal coordinate analysis (PCoA) was performed, using both weighted and unweighted unique fraction metric (UniFrac) distances, to measure the phylogenetic distance between sets of taxa in a phylogenetic tree as the fraction of the branch length of the tree, on the 97\% OTU composition and abundance matrix [29]. The unweighted distance checks for the presence or absence of different taxa of microbial communities between/among samples, whereas the weighted distance investigates proportional changes in the microbial community.

\subsection{Phagocytosis and Oxidative Burst Test}

In order to perform this assay, blood leukocytes (lymphocytes, neutrophils, and monocytes) were incubated with a fluorescent reagent that indicated the production of reactive oxygen species in the basal state, and after carrying out phagocytosis of Staphylococcus aureus bacteria, which indicated the percentage and intensity of phagocytosis. Cells were incubated with the DCFH-DA reagent in phosphate buffered saline (PBS) and DCFH and fluorochrome-labeled (propidium iodide) labeled $S$. aureus and maintained at $37^{\circ} \mathrm{C}$ for $20 \mathrm{~min}$. After this period, the red cells were disrupted with a lysis solution and washed with PBS until a clear-looking sample was obtained. This sample was then read on a FACS Calibur (Becton \& Dickinson, Franklin Lakes, NJ, USA) flow cytometer.

\subsection{Lymphoproliferation Test}

The assay was performed in 96-well microtiter plates with U-shaped bottom. Blood lymphocytes were obtained by separation into iron particles and, after purification and washes in RPMI-1640 medium, were added to the wells in a concentration equivalent to $1 \times 10^{5}$ cells/well in $200 \mu \mathrm{L} /$ well. The mitogens used were Concanavalin $\mathrm{A}$ and Phytohemagglutinin. The plates were incubated for $72 \mathrm{~h}$ at $37^{\circ} \mathrm{C}$ in $5 \% \mathrm{CO}_{2}$ atmosphere. After $72 \mathrm{~h}$ of incubation, cells were collected and evaluation of proliferation was performed on a FACS Calibur (Becton \& Dickinson, Franklin Lakes, NJ, USA) flow cytometer. For the analysis of fluorescence data, the values of the percentage of cell divisions and the index of cell proliferation were considered. In order to obtain and analyze the results, we used the software Cell Queste Flow Jo (TreeStar). 


\subsection{Immunophenotyping of Lymphocytes}

The number of CD4/CD8+ CD4+ CD8+ lymphocytes (CD3/CD4+/CD45R-) and CD4/CD8+ lymphocytes (CD3/CD8+/CD45R-) was assessed. Mononuclear cells $\left(2 \times 10^{5}\right.$ cells $\left./ \mathrm{mL}\right)$ were incubated in microtubes $(1.5 \mathrm{~mL})$ with CD3 (1:100), CD4 (1:10), CD8 (1:20), CD21 (1:100), and CD45R (1:100) (Serotec Antibody, Biolegend and eBioscience), diluted in $100 \mu \mathrm{L}$ of cytometry buffer (PBS containing $0.5 \%$ bovine serum albumin and $0.02 \%$ sodium azide). The isotypic antibodies for background definition were included in the assay. Cells were incubated for $20 \mathrm{~min}$ at $4{ }^{\circ} \mathrm{C}$, protected from light. At the end of the incubation period, the samples were washed twice with buffer for cytometry in a volume of $1000 \mu \mathrm{L} /$ microtube. Finally, the cells were resuspended in $500 \mu \mathrm{L}$ of phosphate buffer. The population of cells with low size (FSC) and low complexity (SSC) according to the delimited gate was selected as the lymphocyte population. From this selection, the different populations of lymphocytes were determined. The acquisition and analysis of 10,000 cells were performed using the flow cytometry technique.

\subsection{Statistical Analysis}

The results were analyzed using the Statistical Analysis System (SAS Institute Inc., Cary, NC, USA, 2004). The normality of the residues was verified by the Shapiro-Wilk test (PROC UNIVARIATE) and the variances compared by the F test. The statistical assumptions underwent logarithmic or square root transformation, and then analysis of variance was performed by PROC GLM of the SAS with the means compared by the Tukey test at $5 \%$ of significance, as well as by simple polynomial regression, considering 2 degrees of freedom (linear and deviation).

The abundances observed for phyla and genera of each animal were evaluated by means of a generalized linear model, considering binomial distribution and a logit link function. The model included the fixed effect of the treatments (OXPC levels: 0.0, 0.3\% or $0.6 \%$ ) in addition to the random effect of the residue. The Tukey multiple comparison test was performed to identify which specific means differed at $5 \%$ significance level. All analyses were performed using the PROC GENMOD of the SAS procedure from the Statistical Analysis System, version 9.4 (SAS Institute Inc., Cary, NC, USA).

\section{Results}

There was no difference between the treatments in relation to the average daily consumption of DM, NM, OM, CP, EEAH, CF, ash, and GE ( $p>0.05$; Table 3). The inclusion levels assessed for OXPC did not influence the ADC of DM, MO, ash, EEAH, and GE $(p>0.05$; Table 3$)$. The presence of additive decreased the digestibility of NFE $(p=0.04), \mathrm{CP}$ $(p=0.01)$, and the metabolizable energy of the diets $(p<0.01)$, but increased the digestibility of CF $(p<0.001)$.

There were no differences for fecal production in organic matter, dry matter, and fecal score $(p>0.05$; Table 4$)$.

The presence of OXPC increased the propionic acid amount compared to that in the control group $(p=0.05)$. The other variables of intestinal fermentation did not differ between the treatments in this study $(p>0.05$; Table 4$)$. There was no difference among treatments regarding VOCs $(p>0.05$; Table 5).

Regarding fecal microbiota, the alpha diversity was measured to determine the number of OTUs and then to give a basic measure of the bacterial diversity within each sample. All samples showed similar rarefaction curves regardless of treatment, indicating that these samples had similar diversity and no treatment effect (Figure 1). The principal coordinate analysis (PCoA) measures the overall bacterial genera relatedness, where the samples with similar bacterial communities are localized in similar positions in the diagram. Figures 2 and 3 suggest that OXPC supplementation at both levels $(0.3 \%$ and $0.6 \%)$ did not have a beta-diversity effect on fecal microbiota. 
Table 3. Intake of nutrients, apparent digestibility coefficients of nutrients, and metabolizable energy from experimental diets with different doses of the additive Original XPC ${ }^{\mathrm{TM}}$ (OXPC) given to the adult dogs.

\begin{tabular}{|c|c|c|c|c|c|}
\hline \multirow{2}{*}{ Item } & \multicolumn{3}{|c|}{ Diets $^{1}$} & \multirow{2}{*}{ SEM $^{2}$} & \multirow{2}{*}{$p$ Value } \\
\hline & $\mathrm{CO}$ & OXPC 0.3 & OXPC 0.6 & & \\
\hline \multicolumn{6}{|c|}{ Consumption (g/day) } \\
\hline Natural matter & 197.33 & 170.67 & 198.00 & 15.07 & 0.75 \\
\hline Dry matter & 187.95 & 156.28 & 180.54 & 14.46 & 0.69 \\
\hline Organic matter & 184.21 & 160.56 & 185.94 & 14.54 & 0.76 \\
\hline Crude protein & 70.37 & 53.34 & 66.08 & 5.37 & 0.45 \\
\hline $\begin{array}{c}\text { Ethereal extract in acid } \\
\text { hydrolysis }\end{array}$ & 30.83 & 27.95 & 28.44 & 2.38 & 0.89 \\
\hline Crude fiber & 13.25 & 12.55 & 13.05 & 1.05 & 0.97 \\
\hline Ash & 13.12 & 10.11 & 12.06 & 0.99 & 0.50 \\
\hline Nitrogen-free extract & 69.76 & 66.72 & 78.37 & 5.91 & 0.74 \\
\hline Gross energy (Kcal/day) & 1031.29 & 891.74 & 1018.82 & 80.56 & 0.77 \\
\hline \multicolumn{6}{|c|}{ Apparent digestibility coefficient (\%) } \\
\hline Dry matter & 85.84 & 85.09 & 85.43 & 0.72 & 0.76 \\
\hline Organic matter & 89.10 & 88.44 & 88.35 & 0.58 & 0.62 \\
\hline Ash & 40.08 & 31.82 & 40.41 & 3.13 & 0.12 \\
\hline Crude protein & $90.56^{\mathrm{a}}$ & $86.90^{\mathrm{c}}$ & $88.62^{b}$ & 0.74 & 0.01 \\
\hline Crude fiber & $60.95^{b}$ & $74.41^{\mathrm{a}}$ & $72.13^{\mathrm{a}}$ & 2.03 & $<0.001$ \\
\hline $\begin{array}{c}\text { Ethereal extract in acid } \\
\text { hydrolysis }\end{array}$ & 94.44 & 95.78 & 95.72 & 0.79 & 0.42 \\
\hline Nitrogen-free extract & $91.02^{\mathrm{a}}$ & $89.24^{b}$ & $88.15^{b}$ & 0.72 & 0.04 \\
\hline Gross energy & 89.69 & 88.78 & 88.60 & 0.56 & 0.36 \\
\hline $\begin{array}{c}\text { Metabolizable energy } \\
\text { (Kcal/kg of food consumed) }\end{array}$ & $4100^{\mathrm{a}}$ & $4003^{b}$ & $3902^{c}$ & 33.38 & $<0.01$ \\
\hline
\end{tabular}

${ }^{1}$ DC (control diet), OXPC 0.3 (control diet with 0.3\% OXPC) and OXPC 0.6 (control diet with $0.6 \%$ OXPC) ${ }^{2} \mathrm{SEM}$, standard error of the mean. ${ }^{\mathrm{a}, \mathrm{b}, \mathrm{c}}$ mean in the lines followed by the same letters do not differ by Tukey test $(p>0.05)$.

The predominant fecal phyla present in all dogs included Firmicutes, Fusobacteria, and Bacteriodetes (Table 6). Together, Firmicutes and Fusobacteria constituted about 85-88\% of the bacterial sequences, and Bacteroidetes contributed $8-12 \%$ of the sequences. An increase $(p=0.0048)$ in the abundance of fecal Actinobacteria was observed as the dose of the OXPC diet increased (Table 6). Besides that, the concentration of Firmicutes increased $(p<0.0001)$ while Fusobacteria decreased with the additive inclusion $(p=0.0008)$. 
Table 4. Fecal quality and production, concentration of lactic acid, short and branched chain fatty acids, and biogenic amines of feces from dogs fed with different doses of the additive Original $\mathrm{XPC}^{\mathrm{TM}}(\mathrm{OXPC})$.

\begin{tabular}{|c|c|c|c|c|c|}
\hline \multirow{2}{*}{ Item } & \multicolumn{3}{|c|}{ Diets ${ }^{1}$} & \multirow{2}{*}{ SEM $^{2}$} & \multirow{2}{*}{$p$ Value } \\
\hline & CD & OXPC 0.3 & OXPC 0.6 & & \\
\hline \multicolumn{6}{|c|}{ Fecal production, fecal quality and lactic acid } \\
\hline Fecal production g MN/dog/day & 85.34 & 73.54 & 88.54 & 14.46 & 0.75 \\
\hline Fecal production g MS/dog/day & 26.16 & 23.11 & 26.37 & 3.86 & 0.80 \\
\hline Fecal score & 3.97 & 3.88 & 3.97 & 0.05 & 0.42 \\
\hline Fecal pH & 6.66 & 6.56 & 6.44 & 0.10 & 0.34 \\
\hline $\mathrm{N}$ ammoniacal & 130.53 & 150.72 & 165.67 & 24.33 & 0.60 \\
\hline Lactic acid & 13.22 & 16.30 & 11.69 & 3.56 & 0.62 \\
\hline \multicolumn{6}{|c|}{ Short chain fatty acids. mmol/ $\mathrm{Kg}$ of dry matter } \\
\hline Acetic acid & 55.02 & 86.47 & 84.17 & 10.00 & 0.07 \\
\hline Propionic acid & $25.77^{\mathrm{b}}$ & $42.98^{\mathrm{a}}$ & $40.80^{\mathrm{a}}$ & 4.94 & 0.05 \\
\hline Butyric acid & 9.41 & 12.04 & 13.00 & 2.16 & 0.49 \\
\hline SCFA $^{3}$ total & 90.21 & 141.5 & 137.98 & 10.05 & 0.07 \\
\hline \multicolumn{6}{|c|}{ Branched chain fatty acids. mmol/ $\mathrm{Kg}$ of dry matter } \\
\hline Valeric acid & - & - & - & - & - \\
\hline Iso-valeric acid & 2.20 & 2.58 & 3.40 & 0.59 & 0.36 \\
\hline Iso-butyric acid & 1.95 & 2.00 & 2.55 & 0.39 & 0.50 \\
\hline SBCFA $^{4}$ total & 4.16 & 4.58 & 5.96 & 0.55 & 0.42 \\
\hline Total fatty acids & 94.36 & 146.08 & 143.94 & 16.46 & 0.07 \\
\hline \multicolumn{6}{|c|}{ Biogenic amines. $\mathrm{mg} / \mathrm{Kg}$ of feces in the of natural matter } \\
\hline Tyramine & 80.38 & 12.47 & 65.91 & 43.88 & 0.53 \\
\hline Putrescin & 130.54 & 92.14 & 106.35 & 26.33 & 0.59 \\
\hline Cadaverine & 54.42 & 18.31 & 37.29 & 24.57 & 0.56 \\
\hline Spermidine & 41.22 & 34.80 & 41.25 & 5.67 & 0.65 \\
\hline Phenylethylamine & - & 4.25 & 3.04 & - & - \\
\hline Tryptamine & 1.81 & 3.18 & 2.44 & - & - \\
\hline Total amines & 271.32 & 155.35 & 223.95 & 41.25 & 0.56 \\
\hline
\end{tabular}

${ }^{1}$ DC (control diet), OXPC 0.3 (control diet with $0.3 \%$ OXPC) and OXPC 0.6 (control diet with $0.6 \%$ OXPC); ${ }^{2}$ SEM standard error of the mean; ${ }^{3}$ SCFA. short chain fatty acids; ${ }^{4}$ SBCFA. short branched chain fatty acids. ${ }^{a, b}$ mean in the lines followed by the same letters do not differ by Tukey test $(p>0.05)$.

Table 5. Mean percentage of the peak area of the most abundant volatile organic compounds present in feces from dogs fed with different doses of the additive Original XPC ${ }^{\mathrm{TM}}$ (OXPC).

\begin{tabular}{|c|c|c|c|c|c|}
\hline \multirow{2}{*}{ Item } & \multicolumn{3}{|c|}{ Diets $^{1}$} & \multirow{2}{*}{ SEM $^{2}$} & \multirow{2}{*}{$p$ Value } \\
\hline & DC & OXPC 0.3 & OXPC 0.6 & & \\
\hline Acetic acid & 12.88 & 13.78 & 12.56 & 3.19 & 0.95 \\
\hline Butanoic acid & 4.52 & 6.26 & 8.33 & 1.47 & 0.28 \\
\hline Ethanol & 1.49 & 3.66 & 7.08 & 1.48 & 0.08 \\
\hline Indol & 6.80 & 14.10 & 7.82 & 2.45 & 0.09 \\
\hline Phenol & 1.59 & 4.18 & 4.26 & 1.10 & 0.24 \\
\hline Propanoic & 11.73 & 15.01 & 14.76 & 2.29 & 0.54 \\
\hline 2-piperidinone & 2.35 & 2.87 & 1.86 & 0.53 & 0.43 \\
\hline
\end{tabular}

${ }^{1}$ DC (control diet), OXPC 0.3 (control diet with $0.3 \%$ OXPC) and OXPC 0.6 (control diet with $0.6 \%$ OXPC); ${ }^{2}$ SEM, standard error of the mean. 

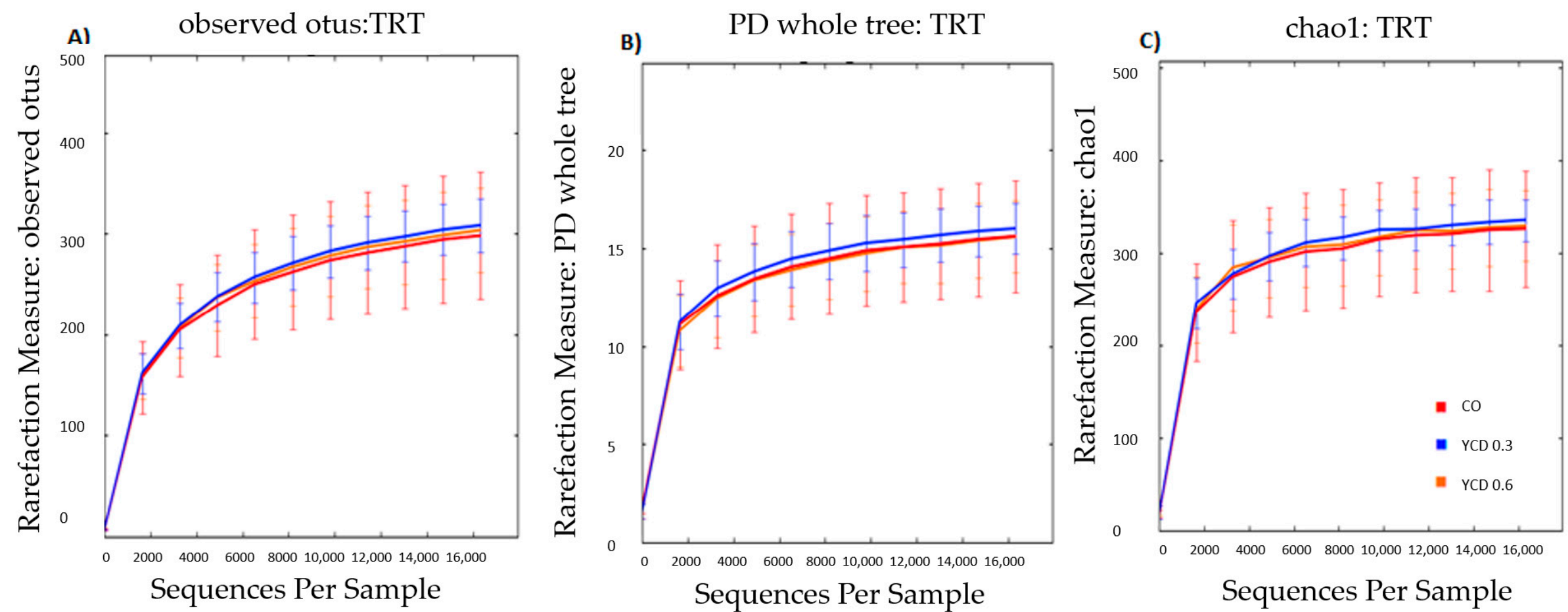

Figure 1. Alpha diversity: Rarefaction curves based on observed operational units (observed OTU) (A), phylogenetic distances (PD whole tree) (B) and metrics (Chao1) (C) according to the diet consumed by the animals. $X$ axis represents the sequence depth (16,300 readings/sample), lines represent the mean of each group (red $=$ control diet, blue $=$ control diet with $0.3 \%$ OXPC, and orange $=$ control diet with $0.6 \%$ OXPC) 


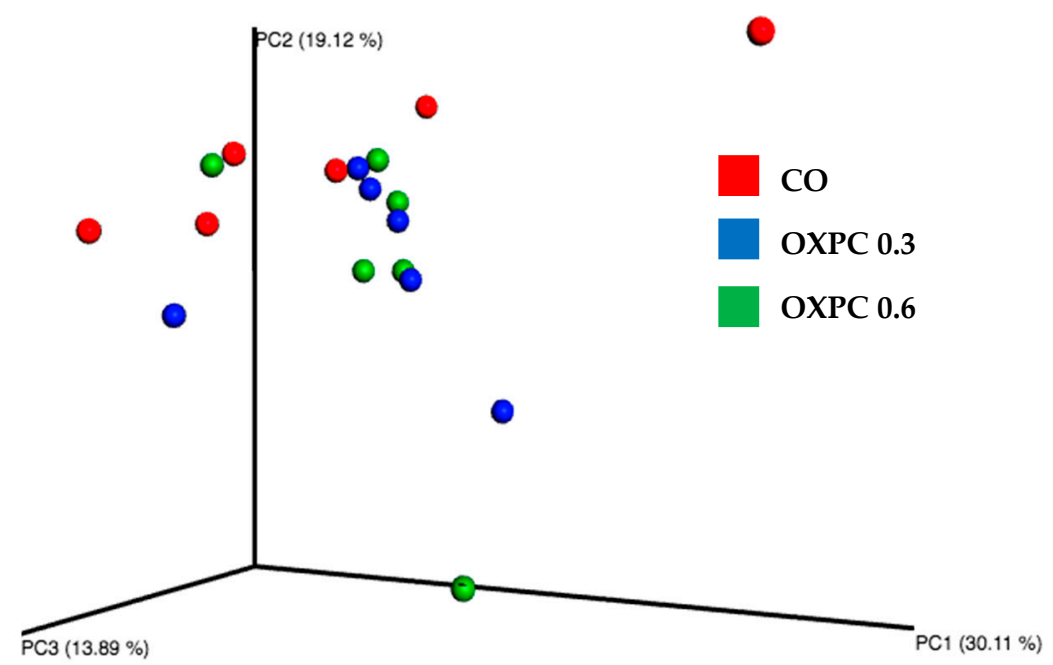

Figure 2. Beta diversity: Principal coordinate analysis (PCoA) of the unweighted portion of the unique metric fraction (Unifrac), according to the diet consumed by the animals. The plot showing clustering of microbial communities from feces of dogs fed with $0 \%$ (red), $0.3 \%$ (blue), and $0.6 \%$ (green) of OXPC. The closer the items, the more similar the microbial communities in the samples.

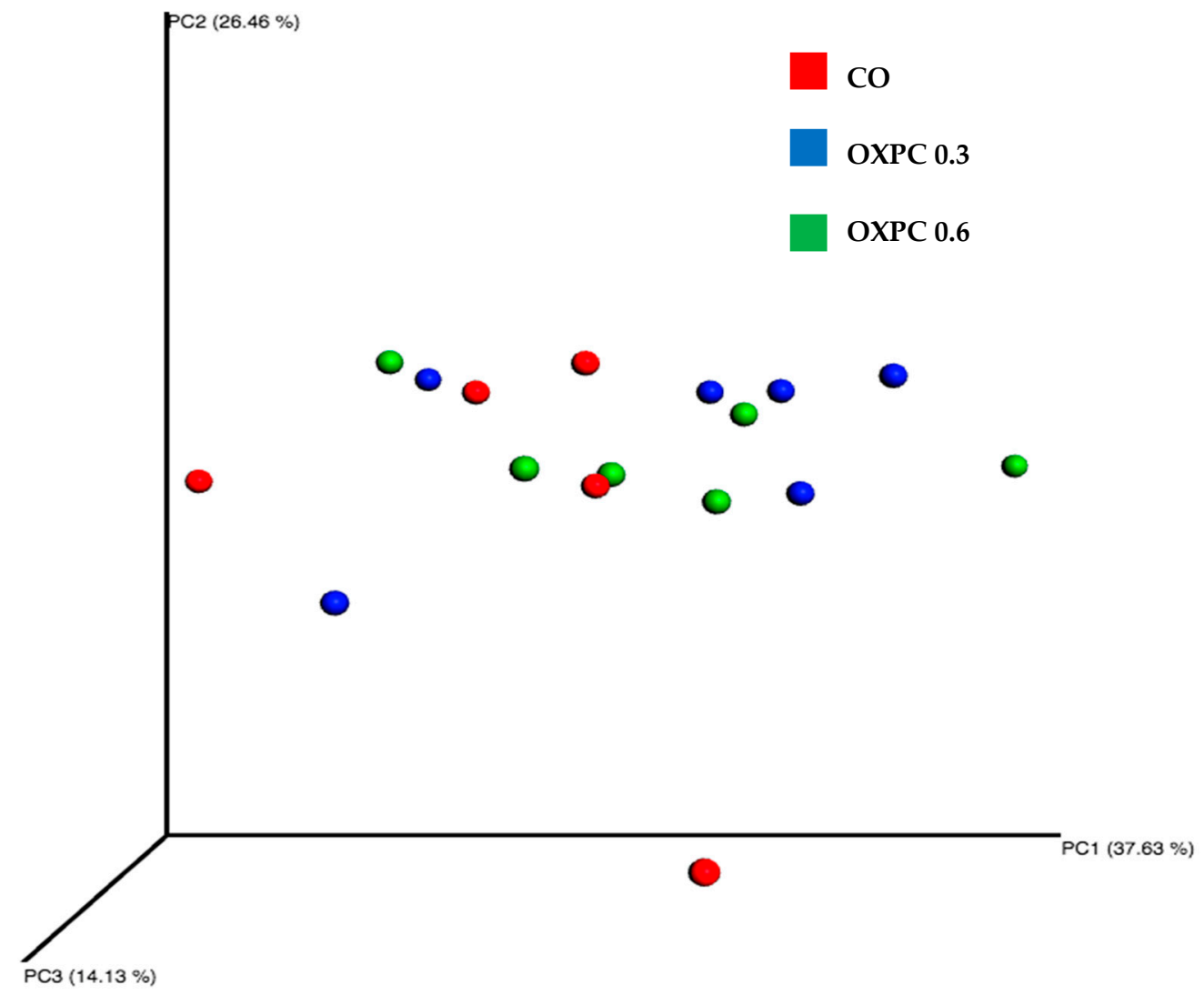

Figure 3. Beta diversity: Principal coordinate analysis (PCOA) of the weighted portion of the unique metric fraction (Unifrac), according to the diet consumed by the animals. The plot showing clustering of microbial communities from feces of dogs fed with $0 \%$ (red), $0.3 \%$ (blue), and $0.6 \%$ (green) OXPC. The closer the items, the more similar the microbial communities in the samples. 
Table 6. Prominent bacterial phyla (expressed as percentage of total sequences) in feces of dogs fed with different doses of the additive Original XPC ${ }^{\mathrm{TM}}(\mathrm{OXPC})$.

\begin{tabular}{|c|c|c|c|c|c|}
\hline \multirow{2}{*}{ Item } & \multicolumn{3}{|c|}{ Diets ${ }^{1}$} & \multirow{2}{*}{ SEM $^{2}$} & \multirow{2}{*}{$p$ Value } \\
\hline & $\mathrm{CO}$ & OXPC 0.3 & OXPC 0.6 & & \\
\hline $\begin{array}{l}\text { Unassigned } \\
\text { bacteria }\end{array}$ & $\begin{array}{c}0.011 \pm \\
0.0004\end{array}$ & $\begin{array}{c}0.010 \pm \\
0.0004\end{array}$ & $\begin{array}{c}0.019 \pm \\
0.0006\end{array}$ & 0.0078 & 0.9886 \\
\hline Actinobacteria & $\begin{array}{c}0.160^{\mathrm{b}} \pm \\
0.0016\end{array}$ & $\begin{array}{c}0.703^{\mathrm{a}, \mathrm{b}} \pm \\
0.0034\end{array}$ & $\begin{array}{c}1.869^{\mathrm{a}} \pm \\
0.0055\end{array}$ & 0.3311 & 0.0048 \\
\hline Bacteroidetes & $\begin{array}{c}11.990 \pm \\
0.0133\end{array}$ & $\begin{array}{c}9.370 \pm \\
0.0119\end{array}$ & $\begin{array}{c}8.150 \pm \\
0.0112\end{array}$ & 30.550 & 0.0768 \\
\hline Deferribacteres & $\begin{array}{c}0.006 \pm \\
0.0003\end{array}$ & $\begin{array}{c}0.019 \pm \\
0.0006\end{array}$ & $\begin{array}{c}0.0101 \pm \\
0.0004\end{array}$ & 0.0088 & 0.9754 \\
\hline Firmicutes & $\begin{array}{c}60.050^{\mathrm{b}} \pm \\
0.0200\end{array}$ & $\begin{array}{c}70.380^{\mathrm{a}} \pm \\
0.0186\end{array}$ & $\begin{array}{c}70.760^{\mathrm{a}} \pm \\
0.0186\end{array}$ & 5.937 & $<0.0001$ \\
\hline Fusobacteria & $\begin{array}{c}25.500^{\mathrm{a}} \pm \\
0.0178\end{array}$ & $\begin{array}{c}17.960^{\mathrm{b}} \pm \\
0.0157\end{array}$ & $\begin{array}{c}17.620^{\mathrm{b}} \pm \\
0.0156\end{array}$ & 41.330 & 0.0008 \\
\hline Proteobacteria & $\begin{array}{c}2.280 \pm \\
0.0061\end{array}$ & $\begin{array}{c}1.560 \pm \\
0.0051\end{array}$ & $\begin{array}{c}1.570 \pm \\
0.0051\end{array}$ & 0.5619 & 0.5709 \\
\hline
\end{tabular}

${ }^{1}$ DC (control diet), OXPC 0.3 (control diet with $0.3 \%$ OXPC), and OXPC 0.6 (control diet with $0.6 \%$ OXPC); ${ }^{2}$ SEM, standard error of the mean. ${ }^{a, b}$ mean in the lines followed by the same letters do not differ by Tukey test $(p>0.05)$.

The predominant fecal bacterial genera were Clostridium (18-25\%), Fusobacterium (16-25\%), and Blautia (7-11\%) (Table 7). The fecal concentrations of Prevotella, Allobaculum, and Fusobacterium were lower after including $\operatorname{OXPC}(p=0.0003, p=0.0265$, and $p=$ 0.0006 respectively; Table 7). The Clostridium proportion increased with OXPC inclusion $(p=0.0059$; Table 7$)$ and the Collinsella proportion was also greater when the highest prebiotic level was supplemented ( $p=0.0052$; Table 7).

Table 7. Prominent bacterial genera (expressed as percentage of total sequences) in feces of dogs fed different doses of the additive Original XPC ${ }^{\mathrm{TM}}$ (OXPC).

\begin{tabular}{|c|c|c|c|c|c|}
\hline \multirow{2}{*}{ Item } & \multicolumn{3}{|c|}{ Diets ${ }^{1}$} & \multirow{2}{*}{ SEM $^{2}$} & \multirow{2}{*}{$p$ Value } \\
\hline & DC & OXPC 0.3 & OXPC 0.6 & & \\
\hline $\begin{array}{c}\text { Unassigned bacteria } \\
\text { Actinobateria }\end{array}$ & $0.012 \pm 0.0004$ & $0.010 \pm 0.0004$ & $0.020 \pm 0.0006$ & 0.0078 & 0.9886 \\
\hline Bifidobacterium & $0.056 \pm 0.0010$ & $0.090 \pm 0.0012$ & $0.016 \pm 0.0005$ & 0.062 & 0.8422 \\
\hline Collinsella & $0.050^{b} \pm 0.009$ & $0.427^{\mathrm{b}} \pm 0.0027$ & $1.441^{\mathrm{a}} \pm 0.0049$ & 0.256 & 0.0052 \\
\hline Slackia & $0.054 \pm 0.0009$ & $0.186 \pm 0.0018$ & $0.412 \pm 0.0026$ & 0.093 & 0.3835 \\
\hline \multicolumn{6}{|l|}{ Bacteroidetes } \\
\hline Bacteroides & $6.946 \pm 0.0104$ & $7.392 \pm 0.0107$ & $6.465 \pm 0.0100$ & 2.356 & 0.8188 \\
\hline Parabacteroides & $0.126 \pm 0.0014$ & $0.070 \pm 0.0011$ & $0.079 \pm 0.0011$ & 0.044 & 0.9446 \\
\hline Prevotella & $3.044^{\mathrm{a}} \pm 0.0070$ & $0.584^{b} \pm 0.0031$ & $0.561^{b} \pm 0.0031$ & 0.355 & 0.0003 \\
\hline $\mathrm{S} 24-7$ & $0.102 \pm 0.0013$ & $0.009 \pm 0.0004$ & $0.007 \pm 0.0003$ & 0.036 & 0.6529 \\
\hline Other [Paraprevotellaceae] & $0.441 \pm 0.0027$ & $0.419 \pm 0.0026$ & $0.234 \pm 0.0020$ & 0.162 & 0.7954 \\
\hline [Paraprevotellaceae] & $0.045 \pm 0.0009$ & $0.035 \pm 0.0008$ & $0.017 \pm 0.0005$ & 0.019 & 0.9581 \\
\hline $\begin{array}{c}\text { [Paraprevotellaceae] } \\
\text { [Prevotella] }\end{array}$ & $1.287 \pm 0.0070$ & $0.863 \pm 0.0031$ & $0.789 \pm 0.0031$ & 0.355 & 0.6505 \\
\hline Deferribacteres & & & & & \\
\hline $\begin{array}{l}\text { Mucispirillum } \\
\text { Firmicutes }\end{array}$ & $0.006 \pm 0.0003$ & $0.019 \pm 0.0006$ & $0.011 \pm 0.0004$ & 0.009 & 0.9754 \\
\hline Lactobacillus & $0.003 \pm 0.0002$ & $0.402 \pm 0.0026$ & $0.003 \pm 0.0002$ & 0.230 & 0.0841 \\
\hline Streptococcus & $0.015 \pm 0.0005$ & $0.061 \pm 0.0010$ & $0.007 \pm 0.0003$ & 0.033 & 0.8391 \\
\hline Turicibacter & $0.108 \pm 0.0013$ & $0.017 \pm 0.0005$ & $0.010 \pm 0.0004$ & 0.047 & 0.6865 \\
\hline Other Clostridiales & $0.290 \pm 0.0022$ & $0.417 \pm 0.0026$ & $0.183 \pm 0.0017$ & 0.137 & 0.7529 \\
\hline Clostridiales & $0.433 \pm 0.0027$ & $0.368 \pm 0.0025$ & $0.457 \pm 0.0028$ & 0.092 & 0.9696 \\
\hline
\end{tabular}


Table 7. Cont.

\begin{tabular}{|c|c|c|c|c|c|}
\hline \multirow{2}{*}{ Item } & \multicolumn{3}{|c|}{ Diets ${ }^{1}$} & \multirow{2}{*}{ SEM $^{2}$} & \multirow{2}{*}{$p$ Value } \\
\hline & DC & ОХРС 0.3 & OXPC 0.6 & & \\
\hline Other Clostridiaceae & $0.175 \pm 0.0017$ & $0.209 \pm 0.0019$ & $0.305 \pm 0.0023$ & 0.043 & 0.8914 \\
\hline Clostridiaceae & $2.641 \pm 0.0065$ & $2.730 \pm 0.0067$ & $2.530 \pm 0.0064$ & 0.348 & 0.9768 \\
\hline Clostridium & $18.185^{b} \pm 0.0158$ & $24.513^{a} \pm 0.018$ & $25.043^{a} \pm 0.0177$ & 3.931 & 0.0059 \\
\hline $\begin{array}{c}\text { Pseudoramibacter } \\
\text { Eubacterium }\end{array}$ & $0.041 \pm 0.0008$ & $0.020 \pm 0.0006$ & $0.004 \pm 0.0003$ & 0.024 & 0.9024 \\
\hline Other Lachnospiraceae & $0.547 \pm 0.0030$ & $0.840 \pm 0.0037$ & $0.801 \pm 0.0036$ & 0.191 & 0.8033 \\
\hline Lachnospiraceae & $3.769 \pm 0.0078$ & $3.402 \pm 0.0074$ & $4.975 \pm 0.0089$ & 0.754 & 0.3603 \\
\hline Blautia & $7.122 \pm 0.0105$ & $10.870 \pm 0.013$ & $9.698 \pm 0.0121$ & 1.573 & 0.0667 \\
\hline Coprococcus & $0.073 \pm 0.0011$ & $0.134 \pm 0.0015$ & $0.198 \pm 0.0018$ & 0.039 & 0.8358 \\
\hline Dorea & $2.404 \pm 0.0063$ & 3.790 .0078 & $3.899 \pm 0.0079$ & 0.620 & 0.2579 \\
\hline Roseburia & $0.031 \pm 0.0007$ & $0.007 \pm 0.0004$ & $0.017 \pm 0.0005$ & 0.009 & 0.9543 \\
\hline [Ruminococcus] & $2.930 \pm 0.0069$ & $4.378 \pm 0.0084$ & $4.314 \pm 0.0083$ & 0.127 & 0.3235 \\
\hline Peptococcus & $0.956 \pm 0.0040$ & $1.299 \pm 0.0046$ & $0.700 \pm 0.0034$ & 0.622 & 0.5734 \\
\hline Peptostreptococcaceae & $0.538 \pm 0.0030$ & $0.237 \pm 0.0020$ & $0.365 \pm 0.0025$ & 0.192 & 0.6946 \\
\hline Ruminococcaceae & $1.639 \pm 0.0052$ & $1.488 \pm 0.0049$ & $1.526 \pm 0.0050$ & 0.277 & 0.9762 \\
\hline Fecalibacterium & $5.828 \pm 0.0096$ & $4.650 \pm 0.0086$ & $5.355 \pm 0.0092$ & 1.162 & 0.6535 \\
\hline Ruminococcus & $0.300 \pm 0.0022$ & $0.190 \pm 0.0018$ & $0.098 \pm 0.0013$ & 0.127 & 0.7235 \\
\hline Megamonas & $0.665 \pm 0.0033$ & $0.980 \pm 0.0040$ & $1.970 \pm 0.0057$ & 0.685 & 0.1052 \\
\hline Phascolarctobacterium & $0.276 \pm 0.0021$ & $0.220 \pm 0.0019$ & $0.151 \pm 0.0016$ & 0.103 & 0.8935 \\
\hline [Mogibacteriaceae] & $0.038 \pm 0.0008$ & $0.001 \pm 0.0001$ & $0.0003 \pm 0.0001$ & 0.011 & 0.8000 \\
\hline Erysipelotrichaceae & $2.825 \pm 0.0068$ & $2.383 \pm 0.0062$ & $2.199 \pm 0.0060$ & 0.525 & 0.7750 \\
\hline Allobaculum & $6.905^{\mathrm{a}} \pm 0.0104$ & $3.850^{\mathrm{b}} \pm 0.079$ & $3.996^{b} \pm 0.0080$ & 3.318 & 0.0265 \\
\hline Catenibacterium & $0.455 \pm 0.0027$ & $1.014 \pm 0.0041$ & $1.016 \pm 0.0041$ & 0.349 & 0.4300 \\
\hline Clostridium & $0.024 \pm 0.0006$ & $0.018 \pm 0.0006$ & $0.020 \pm 0.0006$ & 0.011 & 0.9975 \\
\hline Coprobacillus & $0.056 \pm 0.0010$ & $0.183 \pm 0.0017$ & $0.016 \pm 0.0005$ & 0.041 & 0.5815 \\
\hline [Eubacterium] & $0.781 \pm 0.0036$ & $1.697 \pm 0.0053$ & $0.906 \pm 0.0039$ & 0.390 & 0.2840 \\
\hline \multicolumn{6}{|l|}{ Fusobacteria } \\
\hline Other Fusobacteriaceae & $0.611 \pm 0.0032$ & $0.643 \pm 0.0033$ & $0.692 \pm 0.0034$ & 0.070 & 0.9849 \\
\hline Fusobacterium & $24.888^{a} \pm 0.0177$ & $17.319^{b} \pm 0.015$ & $16.928^{b} \pm 0.0153$ & 4.106 & 0.0006 \\
\hline \multicolumn{6}{|l|}{ Proteobacteria } \\
\hline Sutterella & $0.894 \pm 0.0038$ & $0.487 \pm 0.0028$ & $0.300 \pm 0.0022$ & 0.277 & 0.3770 \\
\hline Campylobacter & $0.000 \pm 0.0000$ & $0.051 \pm 0.0009$ & $0.016 \pm 0.0005$ & 0.028 & 0.8022 \\
\hline Succinivibrionaceae & $0.031 \pm 0.0007$ & $0.004 \pm 0.0003$ & $0.278 \pm 0.0022$ & 0.103 & 0.2653 \\
\hline Anaerobiospirillum & $1.328 \pm 0.0047$ & $0.865 \pm 0.0038$ & $0.956 \pm 0.0040$ & 0.371 & 0.7132 \\
\hline Enterobacteriaceae & $0.024 \pm 0.0006$ & $0.148 \pm 0.0016$ & $0.015 \pm 0.0005$ & 0.084 & 0.6069 \\
\hline
\end{tabular}

${ }^{1}$ DC (control diet), OXPC 0.3 (control diet with 0.3\% OXPC), and OXPC 0.6 (control diet with $0.6 \%$ OXPC); 2 SEM, standard error of the mean. ${ }^{a, b}$ mean in the lines followed by the same letters do not differ by Tukey test $(p>0.05)$.

There was no difference for CD4+ and CD8+ lymphocytes, CD4+/CD8+ ratio, oxidative burst (baseline and SAPI and PMA induced), and lymphocyte proliferative response $(p>0.05$; Table 8$)$. However, the phagocytosis index was higher with inclusion of OXPC compared to that of control $(p=0.01)$. 
Table 8. Results of lymphocyte immunophenotyping, phagocytosis test, proliferation, and oxidative burst of dogs fed different doses of the additive Original XPC ${ }^{\mathrm{TM}}$ (OXPC).

\begin{tabular}{|c|c|c|c|c|c|}
\hline \multirow{2}{*}{ Item } & \multicolumn{3}{|c|}{ Diets $^{1}$} & \multirow{2}{*}{ SEM $^{2}$} & \multirow{2}{*}{$p$ Value } \\
\hline & DC & OXPC 0.3 & OXPC 0.6 & & \\
\hline $\begin{array}{c}\text { CD4+ \% (T helper } \\
\text { cells) }\end{array}$ & 28.66 & 28.33 & 28.83 & 1.28 & 0.96 \\
\hline $\begin{array}{c}\text { CD8+ \% (cytotoxic T } \\
\text { cells) }\end{array}$ & 15.16 & 14.33 & 16.83 & 0.87 & 0.15 \\
\hline CD4+/CD8+ & 6.26 & 2.16 & 1.56 & 1.77 & 0.16 \\
\hline Basal oxidative burst & 216.17 & 206.50 & 196.83 & 8.00 & 0.26 \\
\hline Oxidative burst SAPI ${ }^{3}$ & 497.83 & 575.83 & 507.00 & 29.45 & 0.15 \\
\hline Oxidative burst PMA 4 & 764.33 & 778.00 & 774.67 & 60.51 & 0.98 \\
\hline Phagocytosis index & $264.67^{b}$ & $295.17^{\mathrm{a}}$ & $297.17^{a}$ & 7.38 & 0.01 \\
\hline Proliferation index & 310.33 & 355.50 & 356.17 & 16.14 & 0.10 \\
\hline
\end{tabular}

${ }^{1}$ DC (control diet), OXPC 0.3 (control diet with 0.3\% OXPC), and OXPC 0.6 (control diet with 0.6\% OXPC)

${ }^{2}$ SEM, standard error of the mean; ${ }^{3}$ SAPI, Staphylococcus aureus conjugated with propidium iodide; ${ }^{4}$ PMA, phorbol 12-myristate 13-acetate. ${ }^{a, b}$ mean in the lines followed by the same letters do not differ by Tukey test $(p>0.05)$.

\section{Discussion}

Few studies have evaluated nutrient digestibility in dogs fed with diets supplemented with additives similar to OXPC, such as MOS mixed with basal diet [10], spray-dried yeast cell wall [30], S. cerevisiae live yeast [31], or S. cerevisiae fermentation product [6], among others. Different results were found with regard to nutrient digestibility that mentioned increases, decreases, and even non-alteration. Therefore, there is no consensus on the influence of the addition of this additive on digestibility parameters. Nonetheless, in this study, there was a decrease in ADC of CP and NFE and an increase in the ADC of the $\mathrm{CF}$. The increase in intestinal microbial biomass caused by the inclusion of prebiotics in the diet may reduce ADC of $\mathrm{CP}$ [30]. Fecal bacterial mass enhances fecal protein content, which implicates in less ADC compared to the control group. Ideally, the true digestibility coefficient of the protein should be evaluated, in order to avoid considering fecal microbial protein content [32]. In regard to NFE digestibility, the OXPC consisted of dehydrated yeast culture, which has soluble fiber in its composition. That may have increased the viscosity of the bolus and impaired the interaction of pancreatic enzymes with the substrate, thereby decreasing the rate of carbohydrate digestion by pancreatic amylase [33].

Although the ADC of CF increased, this result must be evaluated with caution. The methodology used to determine $\mathrm{CF}$ was not entirely satisfactory. The laboratory technique is deficient because it yields low estimates of the fiber fraction present in the samples, destroying all of the soluble fraction and part of the insoluble fraction [34]. The main limitation is related to the fact that it does not separate cellulose from hemicellulose and causes loss of lignin (which is not considered carbohydrate) and hemicellulose. This method provides values that may change due to very drastic digestion, which leads to the loss of some components, and therefore, the values and differences obtained in our study may not be accurate [35]. The differences found in the metabolizable energy content of the foods may be actually a reflection of the small variations in the crude energy of the diets and levels and types of fibers.

Regarding fecal $\mathrm{pH}$, no differences were observed among treatments, as well as in the study developed by Swanson et al. [4], who supplemented dogs with $2 \mathrm{~g}$ of FOS plus $1 \mathrm{~g}$ MOS. It is known that lactate produced by lactobacillus can lower fecal $\mathrm{pH}$ [36], and in this study, the authors attributed the non-detection of some bacterial species that consume lactate to this absence of differences in the results of fecal $\mathrm{pH}$. Besides that, the SCFAs are absorbed quickly in the intestine, and may not be possible to identify in large amounts in feces that could have masked minor effects on $\mathrm{pH}$ [4].

In our study, the addition of OXPC at the concentrations of 0.3 and $0.6 \%$ were not capable of altering this genus population, which may have been implicated in the lack of 
lactic acid alteration. In addition, in a study by Vickers et al. [37], the authors evaluated the fermentation characteristics of different substrates found in canine diets and could observe an increase in lactate with the use of FOS; however, when MOS was used, this product had its concentration decreased. Saccharomyces cerevisae processing or concentration also may explain the differences in these results.

Volatile organic compounds (VOCs) reflect differences in diet, intestinal microbiota, and exposure to chemical contaminants, as they are usually generated by the metabolism of intestinal microorganisms [38]. In this study, the main fecal VOCs did not change among treatments, which can be considered a positive effect, once it is related to lower stool odor [39]. In dogs, the presence of fecal VOCs was identified with the inclusion of prebiotics [40].

Total SCFAs did not change with OXPC addition, which can be explained by their rapid absorption by colonocytes, reducing fecal detection by presenting smaller quantities in feces [4]. These findings corroborate other studies $[9,12,31]$. SCFAs are associated with cell proliferation due to their role in the energy metabolism of colonocytes and are among the products generated in prebiotic fermentation [41]. Among them, propionic acid showed a higher fecal concentration in dogs treated with OXPC. The MOS present in OXPC reduces colonization by pathogenic bacteria in the intestine by competitive exclusion [30], which may result in an increase in propionic acid.

Biogenic amines are putrefactive compounds that can cause damage to intestinal health [42]. The extra source of energy promoted by fermentable carbohydrates, undigested protein, and their metabolites are used by bacteria for protein synthesis, decreasing the fecal concentration of protein-derived fermentation compounds [43]. No difference between treatments was observed for biogenic amines, which also corroborates the results of Swanson et al. [4].

According to Slavin [44], the level of inclusion of the prebiotic, as well as its source and time of use, can influence its effect. In a recent study, Perini et al. [45] compared the efficacy of prebiotics over 30 and 60 days of supplementation, and observed some changes in fermentation products over time. Therefore, the period of 21 days may not have been long enough to observe the effects of these prebiotics on the fermentative products evaluated in this study.

The microbial balance in the gastrointestinal tract is mostly determined by diet, and prebiotics can influence the gastrointestinal microbiota [46]. Likewise, evaluating the effect of adding a fermented S. cerevisae dry product in vitro, Possemiers et al. [47] did not find strong changes in the microbial community composition of the mucosal associated microbiota.

The predominant microbial phyla in the canine and feline gut, reported by previous investigations are Firmicutes, Bacteroidetes, Proteobacteria, Fusobateria, and Actinobacteria. Fusobacteria is one of the predominant phyla in the intestinal microbiome (intestine or feces). It frequently represents $10 \%$ or more of the genera sequences that inhabit the intestine [32]. This characteristic was also observed in this study, where the predominant fecal phyla present in all dogs included Firmicutes, Fusobacteria, Bacteriodetes, Proteobacteria, Actinobacteria, and Deferribacteres.

Middelbos et al. [48] phylogenetically characterized the fecal microbiota of healthy dogs with 454 pyrosequencing for the first time. The dominant phyla were Fusobacteria (23-40\% of the readings), followed by Firmicutes (14-28\% of the readings), Bacteroidetes (31-34\% of the readings), Actinobacteria (0.8-1.4\% of the readings), and Proteobacteria (5-7\% of readings). Although Fusobacteria was not the most dominant, it was among the phyla with the highest proportion. It was also observed in the study of Beloshapka et al. [46], in which Fusobacteria and Firmicutes constituted about 75-80\% of the bacterial sequences, with Bacteroidetes, Proteobacteria, and Actinobacteria contributing only about 10-15\%, 5\%, and $2-3 \%$ of the sequences, respectively.

An increase in lactobacilli, bifidobacterium, and aerobic bacteria was reported when supplementing the diet of healthy dogs with a combination of $2 \mathrm{~g}$ FOS and $1 \mathrm{~g}$ MOS [4], as FOS is preferentially fermented by lactic acid-producing bacteria [49]. This effect may have 
been evidenced by the type of additive used and its processing, and for this reason, this result was not observed in our study.

The abundance of fecal Actinobacteria increased with the highest dose of OXPC in the diet and has also been observed in cats fed a diet containing a prebiotic [50]. This increase was correlated to microbiota adaptation of the prebiotic, which led to the increase in a genus belonging to the phylum Actinobacteria. The same may have occurred in this study, where the presence of OXPC stimulated the increase in the genus Collinsella, which belongs to the phylum Actinobacteria that was responsible for this increase. In the same way, an increase in Clostridium was observed, which may be correlated with the increase in the Firmicutes phylum, to which it belongs.

The members of the phylum Firmicutes, especially those of the genus Clostridium, can provide some benefits to the animals and are positively correlated with the oxidation of carbohydrates [51]. Although clostridial species are not all considered negative [52], an increase in the population of a potentially pathogenic bacterial genus could be considered a disadvantage of adding OXPC to dog's diet. Despite this, the animals did not shown clinical signs of infection, so it is reasonable to associate the increase in Clostridium with non-pathogenic strains.

Allobaculum also belongs to the Firmicutes phylum and is associated with weight regulation and regulation of hormones known to influence energy homeostasis (e.g., leptin) [53]. Fusobacterium reduction was observed with the inclusion of OXPC in the diet of the animals. This effect is considered beneficial since this genus is associated with gastrointestinal diseases [54,55].

Previous studies have shown an association of the genus Prevotella with diets containing high concentrations of carbohydrates [56,57]. However, the addition of OXPC reduced the concentration of this genus to the detriment of the others, which highlights the importance of conducting investigations on the interactions between bacterial populations and dietary substrates. We hypothesized that a greater inclusion of OXPC would allow the capture of evident differences among the bacterial groups.

Among the immunological tests performed in the study, the phagocytosis index presented greater activity in the animals that were supplemented with OXPC (0.3 and 0.6) compared to control. Few studies have assessed the effect of including this prebiotic on the immunity of pets; the pioneers were Middelbos et al. [3], who did not find differences in the immunity of dogs with the use of blends containing beet pulp, cellulose or blends of cellulose, fructooligosaccharides, and yeast cell wall at $2.5 \%$ in the diet. However, another study that evaluated MOS supplementation observed an increase in the total percentage of white blood cells [4]. A more recent study demonstrated that the inclusion of $1.0 \%$ of a commercial blend containing MOS, FOS, GOS, and beta-glucan in healthy dogs increased the polymorphonuclear cell count, phagocytosis index, and oxidative burst in supplemented animals compared to the control group [58]. Finally, Lin et al. [59] observed that supplementation of $0.2 \%$ yeast cell wall fractions to dogs tended to increase fecal $\operatorname{IgA}$ concentrations. All of the aforementioned suppliers concluded that this finding is related to positive modulation of the immune system.

Studies in other species show that the beta-glucans and MOS contained in S. cerevisiae have been identified as agents capable of triggering strong antigenic stimuli and immune responses. Beta-glucan is designated as an immunological response modifier, for when recognized by the organism, it has the ability to trigger a series of events in the immune response. Kubala et al. [60] reported that modulation of cellular activity by beta-glucan begins with the activation of macrophages, endothelial and dendritic cells, and $\mathrm{B}$ and $\mathrm{T}$ cells. In addition, they involve the specific immune response by inducing the expression of various cytokines such as TNF, IL-6, IL-8, and IL-12 [61]. Therefore, the composition of the OXPC treatment (0.3 and 0.6) explains the improvement in the index of phagocytosis in supplemented dogs. 


\section{Conclusions}

According to the results, the addition of 0.3 and $0.6 \%$ OXPC in the diet of dogs was able to alter some phyla and genera abundances to increase propionic acid production and the phagocytosis index in healthy adult dogs with minor alteration in digestibility. Other studies should evaluate higher doses of OXPC supplementation and its effects on the intestine of healthy dogs and those suffering from gastrointestinal disorders.

Author Contributions: Investigation, K.d.M.S., L.W.R., M.F.R., A.R.A., R.B.A.R., M.I.G.U., T.H.A.V., C.d.O.M. and J.P.F.S.; Methodology, M.A.B., K.d.M.S., J.P.F.S., L.W.R., M.F.R., A.R.A., R.B.A.R., M.I.G.U., T.H.A.V., R.V.V., J.C.d.C.B. and R.V.V.; Resources, C.F.F.P. and M.A.B.; Writing-original draft, K.d.M.S., L.W.R., M.F.R., A.R.A., R.B.A.R., T.H.A.V. and M.A.B.; Writing-review and editing, T.H.A.V., C.F.F.P. and M.A.B. All authors have read and agreed to the published version of the manuscript.

Funding: This research received no external funding.

Institutional Review Board Statement: All experimental procedures were approved by the Ethics Research Committee for Animal Welfare of the School of Veterinary Medicine and Animal Science, University of São Paulo (protocol number 9148270415).

Informed Consent Statement: Not applicable.

Data Availability Statement: The data presented in this study are available on request from the corresponding author.

Acknowledgments: We would like to thank Premier Pet (Grandfood Ind. Com. LTDA) for the construction and maintenance of Pet Nutrology Research Center; and the first author acknowledges the scholarship granted by FAPESP-Fundação de Amparo à Pesquisa do Estado de São Paulo (process 2015/05493-0).

Conflicts of Interest: The authors declare no conflict of interest.

\section{References}

1. Gibson, G.R.; Hutkins, R.; Sanders, M.E.; Prescott, S.L.; Reimer, R.A.; Salminen, S.J.; Scott, K.; Stanton, C.; Swanson, K.S.; Cani, P.D.; et al. Expert consensus document: The International Scientific Association for Probiotics and Prebiotics (ISAPP) consensus statement on the definition and scope of prebiotics. Nat. Rev. Gastroenterol. Hepatol. 2017, 14, 491-502. [CrossRef]

2. Bindels, L.B.; Delzenne, N.M.; Cani, P.D.; Walter, J. Opinion: Towards a more comprehensive concept for prebiotics. Nat. Rev. Gastroenterol. Hepatol. 2015, 12, 303-310. [CrossRef]

3. Middelbos, I.S.; Fastinger, N.D.; Fahey, G.C. Evaluation of fermentable oligosaccharides in diets fed to dogs in comparison to fiber standards. J. Anim. Sci. 2007, 85, 3033-3044. [CrossRef] [PubMed]

4. Swanson, K.S.; Grieshop, C.M.; Flickinger, E.A.; Bauer, L.L.; Healy, H.-P.; Dawson, K.A.; Merchen, N.R.; Fahey, G.C., Jr. Supplemental Fructooligosaccharides and Mannanoligosaccharides Influence Immune Function, Ileal and Total Tract Nutrient Digestibilities, Microbial Populations and Concentrations of Protein Catabolites in the Large Bowel of Dogs. J. Nutr. 2002, 132, 980-989. [CrossRef]

5. Grieshop, C.M.; Flickinger, E.A.; Bruce, K.J.; Patil, A.R.; Czarnecki-Maulden, G.L.; Fahey, G.C. Gastrointestinal and immunological responses of senior dogs to chicory and mannan-oligosaccharides. Arch. Anim. Nutr. 2004, 58, 483-494. [CrossRef] [PubMed]

6. Roberfroid, M. Functional food concept and its application to prebiotics. Dig Liver Dis. 2002, 34 (Suppl. 2), S105-S110. [CrossRef]

7. Snart, J.; Bibiloni, R.; Grayson, T.; Lay, C.; Zhang, H.; Allison, G.E.; Laverdiere, J.K.; Temelli, F.; Vasanthan, T.; Bell, R.; et al. Supplementation of the diet with high-viscosity beta-glucan results in enrichment for lactobacilli in the rat cecum. Appl. Environ. Microbiol. 2006, 72, 1925-1931. [CrossRef]

8. Hughes, S.A.; Shewry, P.R.; Gibson, G.R.; McCleary, B.V.; Rastall, R.A. In vitro fermentation of oat and barley derived $\beta$-glucans by human faecal microbiota. FEMS Microbiol. Ecol. 2008, 64, 482-493. [CrossRef]

9. Lin, C.-Y.; Celesye, A.; Steelman, A.J.; Warzecha, C.M.; Godoy, M.R.C.; Swanson, K.S. Effects of a Saccharomyces cerevisiae fermentation product on fecal characteristics, nutrient digestibility, fecal fermentative end-products, fecal microbial populations, immune function, and diet palatability in adult dogs. J. Anim. Sci. 2019, 97, 1586-1599. [CrossRef] [PubMed]

10. Zentek, J.; Marquart, B.; Pietrzak, T. Intestinal Effects of Mannanoligosaccharides, Transgalactooligosaccharides, Lactose and Lactulose in Dogs. J. Nutr. 2002, 132, 1682S-1684S. [CrossRef]

11. Propst, E.L.; Flickinger, E.A.; Bauer, L.L.; Merchen, N.R.; Fahey, G.C. A dose-response experiment evaluating the effects of oligofructose and inulin on nutrient digestibility, stool quality, and fecal protein catabolites in healthy adult dogs. J. Anim. Sci. 2003, 81, 3057-3066. [CrossRef] 
12. Pawar, M.M.; Pattanaik, A.K.; Sinha, D.K.; Goswami, T.K.; Sharma, K. Effect of dietary mannanoligosaccharide supplementation on nutrient digestibility, hindgut fermentation, immune response and antioxidant indices in dogs. J. Anim. Sci. Technol. 2017, 59, 11. [CrossRef] [PubMed]

13. de Souza, T.S.; Putarov, T.C.; Tiemi, C.; Volpe, L.M.; de Oliveira, C.A.F.; de Abreu, G.M.B.; Carciofi, A.C. Effects of the solubility of yeast cell wall preparations on their potential prebiotic properties in dogs. PLoS ONE 2019, 14, e0215332.

14. Association of American Feed Control Official. AAAFCO methods for substantiating nutritional adequacy of dog and cat food. In AAFCO Dog Cat Food Nutrient Profiles; Association of American Feed Control Officials: Champaign, IL, USA, 2016.

15. National Research Council. Nutrient Requirements of Dogs and Cats; National Academies Press: Washington, DC, USA, 2006.

16. Association of Official Agricultural Chemists. Official Methods of Analysis of AOAC International, 17th ed.; Association of Official Analysis Chemists International: Arlington, VA, USA, 2006.

17. Carciofi, A.C.; Takakura, F.S.; De Oliveira, L.D.; Teshima, E.; Jeremias, J.T.; Brunetto, M.A.; Prada, F. Effects of six carbohydrate sources on dog diet digestibility and post-prandial glucose and insulin response. J. Anim. Physiol. Anim. Nutr. 2008, 92, 326-336. [CrossRef]

18. Walter, M.; Silva, L.P.; Perdomo, D.M.X. Biological response of rats to resistant starch Resposta biológica de ratos ao amido resistente. Rev. Inst. Adolfo Lutz. 2005, 64, 252-257.

19. Sá, F.C.; Vasconcellos, R.S.; Brunetto, M.A.; Filho, F.O.R.; Gomes, M.O.S.; Carciofi, A.C. Enzyme use in kibble diets formulated with wheat bran for dogs: Effects on processing and digestibility. J. Anim. Physiol. Anim. Nutr. 2013, 97, 51-59. [CrossRef]

20. Valente, A.L.P.; Augusto, F. As espessuras dos recobrimentos L. Quim. Nova 2000, 23, 523-530. [CrossRef]

21. Silva, B.J.G.; Lanças, F.M.; Queiroz, M.E.C. In-tube solid-phase microextraction coupled to liquid chromatography (in-tube SPME/LC) analysis of nontricyclic antidepressants in human plasma. J. Chromatogr. B Anal. Technol. Biomed. Life Sci. 2008, 862, 181-188. [CrossRef] [PubMed]

22. Erwin, E.S.; Marco, G.J.; Emery, E.M. Volatile Fatty Acid Analyses of Blood and Rumen Fluid by Gas Chromatography. J. Dairy Sci. 1961, 44, 1768-1771. [CrossRef]

23. Pryce, J.D. A modification of the Barker-Summerson method for the determination of lactic acid. Analyst 1969, 94, 1151-1152. [CrossRef]

24. Vale, S.R.; Glória, B.A. Determination of biogenic amines in cheese. J. AOAC 1997, 80, 1006-1012. [CrossRef]

25. de Gomes, M.O.S.; Beraldo, M.C.; Putarov, T.C.; Brunetto, M.A.; Zaine, L.; Glória, M.B.A.; Carciofi, A.C. Old beagle dogs have lower faecal concentrations of some fermentation products and lower peripheral lymphocyte counts than young adult beagles. Br. J. Nutr. 2011, 106, 187-190. [CrossRef]

26. McInnes, P.; Cutting, M. Manual of Procedures for Human Microbiome Project: Core Microbiome Sampling Protocol A HMP Protocol \# 07-001, Version 12.0. 2010. Available online: http://hmpdacc.org/resources/tools_protocols.php (accessed on 13 March 2021).

27. Caporaso, J.G.; Lauber, C.L.; Walters, W.A.; Berg-Lyons, D.; Huntley, J.; Fierer, N.; Owens, S.M.; Betley, J.; Fraser, L.; Bauer, M.; et al. Ultra-high-throughput microbial community analysis on the Illumina HiSeq and MiSeq platforms. ISME J. 2012, 6, 1621-1624. [CrossRef] [PubMed]

28. Caporaso, J.G.; Kuczynski, J.; Stombaugh, J.; Bittinger, K.; Bushman, F.D.; Costello, E.K.; Fierer, N.; Peña, A.G.; Goodrich, J.K.; Gordon, J.I.; et al. QIIME allows analysis of high- throughput community sequencing data Intensity normalization improves color calling in SOLiD sequencing. Nat. Publ. Gr. 2010, 7, 335-336.

29. Lozupone, C.; Knight, R. UniFrac: A new phylogenetic method for comparing microbial communities. Appl. Environ. Microbiol. 2005, 71, 8228-8235. [CrossRef] [PubMed]

30. Middelbos, I.S.; Godoy, M.R.; Fastinger, N.D.; Fahey, G.C. A dose-response evaluation of spray-dried yeast cell wall supplementation of diets fed to adult dogs: Effects on nutrient digestibility, immune indices, and fecal microbial populations. J. Anim. Sci. 2007, 85, 3022-3032. [CrossRef]

31. Stercova, E.; Kumprechtova, D.; Auclair, E.; Novakova, J. Effects of live yeast dietary supplementation on nutrient digestibility and fecal microflora in beagle dogs. J. Anim. Sci. 2016, 94, 2909-2918. [CrossRef] [PubMed]

32. Deng, P.; Swanson, K.S. Gut microbiota of humans, dogs and cats: Current knowledge and future opportunities and challenges. Br. J. Nutr. 2015, 113, 6-17. [CrossRef]

33. El Khoury, D.; Cuda, C.; Luhovyy, B.L.; Anderson, G.H. Beta glucan: Health benefits in obesity and metabolic syndrome. J. Nutr. Metab. 2012, 2012, 851362. [CrossRef]

34. Cecchi, H.M. Fundamentos Teóricos e Práticos em Análise de Alimentos, 2nd ed.; Universidade Estadual de Campinas (UNICAMP), Ed.; Universidade Estadual de Campinas: Campinas, Brazil, 2003.

35. de Oliveira, L.D.; Takakura, F.S.; Kienzle, E.; Brunetto, M.A.; Teshima, E.; Pereira, G.T.; Carciofi, A.C. Fibre analysis and fibre digestibility in pet foods-A comparison of total dietary fibre, neutral and acid detergent fibre and crude fibre. J. Anim. Physiol. Anim. Nutr. 2012, 96, 895-906. [CrossRef] [PubMed]

36. Hammes, W.P.; Vogel, R.F. The Genus lactobacillus. In The Genera of Lactic Acid Bacteria; Springer: Boston, MA, USA, $1995 ;$ pp. 19-54.

37. Vickers, R.J.; Sunvold, G.D.; Kelley, R.L.; Reinhart, G.A. Comparison of fermentation of selected fructooligosaccharides and other fiber substrates by canine colonic microflora. Am. J. Vet. Res. 2001, 62, 609-615. [CrossRef]

38. Garner, C.E.; Smith, S.; Lacy, C.B.; White, P.; Spencer, R.; Probert, C.S.J.; Ratcliffem, N.M. Volatile organic compounds from feces and their potential for diagnosis of gastrointestinal disease. FASEB J. 2007, 21, 1675-1688. [CrossRef] 
39. Bastos, T.S.; de Lima, D.C.; Souza, C.M.M.; Maiorka, A.; de Oliveira, S.G.; Bittencourt, L.C.; Félix, A.P. Bacillus subtilis and Bacillus licheniformis reduce faecal protein catabolites concentration and odour in dogs. BMC Vet. Res. 2020, 16, 116. [CrossRef] [PubMed]

40. Hesta, M.; Janssens, G.P.J.; Debraekeleer, J.; De Wilde, R. The effect of oligofructose and inulin on faecal characteristics and nutrient digestibility in healthy cats. J. Anim. Physiol. Anim. Nutr. 2001, 85, 135-141. [CrossRef] [PubMed]

41. Walker, W.A.; Duffy, L.C. Diet and bacterial colonization: Role of probiotics and prebiotics. J. Nutr. Biochem. 1998, 9, 668-675. [CrossRef]

42. Wollowski, I.; Rechkemmer, G.; Pool-Zobel, B.L. Protective role of probiotics and prebiotics in colon cancer. Am. J. Clin. Nutr. 2001, 73, 451s-455s. [CrossRef] [PubMed]

43. Cummings, J.H.; Hill, M.J.; Bone, E.S.; Branch, W.J.; Jenkins, D.J. The effect of meat protein and dietary fiber on colonic function and metabolism. II. Bacterial metabolites in feces and urine. Am. J. Clin. Nutr. 1979, 32, 2094-2101. [CrossRef] [PubMed]

44. Slavin, J. Fiber and prebiotics: Mechanisms and health benefits. Nutrients 2013, 5, 1417-1435. [CrossRef]

45. Perini, M.P.; Rentas, M.F.; Pedreira, R.; Amaral, A.R.; Zafalon, R.V.A.; Rodrigues, R.B.A.; Henríquez, L.B.F.; Zanini, L.; Vendramini, T.H.A.; Balieiro, J.C.C.; et al. Duration of prebiotic intake is a key-factor for diet-induced modulation of immunity and fecal fermentation products in dogs. Microorganisms 2020, 8, 1916. [CrossRef]

46. Beloshapka, A.N.; Dowd, S.E.; Suchodolski, J.S.; Steiner, J.M.; Duclos, L.; Swanson, K.S. Fecal microbial communities of healthy adult dogs fed raw meat-based diets with or without inulin or yeast cell wall extracts as assessed by 454 pyrosequencing. FEMS Microbiol. Ecol. 2013, 84, 532-541. [CrossRef]

47. Possemiers, S.; Pinheiro, I.; Verhelst, A.; Van Den Abbeele, P.; Maignien, L.; Laukens, D.; Reeves, S.G.; Robinson, L.E.; Raas, T.; Schneider, Y.-J.; et al. A dried yeast fermentate selectively modulates both the luminal and mucosal gut microbiota and protects against inflammation, as studied in an integrated in vitro approach. J. Agric. Food Chem. 2013, 61, 9380-9392. [CrossRef]

48. Middelbos, I.S.; Boler, B.M.V.; Qu, A.; White, B.A.; Swanson, K.S.; Fahey, G.C. Phylogenetic Characterization of Fecal Microbial Communities of Dogs Fed Diets with or without Supplemental Dietary Fiber Using 454 Pyrosequencing. PLoS ONE 2010, 5, e9768. [CrossRef] [PubMed]

49. Hidaka, H.; Eida, T.; Takizawa, T.; Tokunaga, T.; Tashiro, Y. Effects of Fructooligosaccharides on Intestinal Flora and Human Health. Bifidobact. Microflora 1986, 5, 37-50. [CrossRef]

50. Barry, K.A.; Middelbos, I.S.; Vester Boler, B.M.; Dowd, S.E.; Suchodolski, J.S.; Henrissat, B.; Coutinho, P.M.; White, B.A.; Fahey, J.G.C.; Swanson, K.S. Effects of dietary fiber on the feline gastrointestinal metagenome. J. Proteome Res. 2012, 11, 5924-5933. [CrossRef]

51. Kelder, T.; Stroeve, J.H.M.; Bijlsma, S.; Radonjic, M.; Roeselers, G. Correlation network analysis reveals relationships between diet-induced changes in human gut microbiota and metabolic health. Nutr. Diabetes 2014, 4, 122-127. [CrossRef] [PubMed]

52. Van Rijssel, M.; Hansen, T.A. Clostridium thermosaccharolyticum strain. FEMS Microbiol. Lett. 1989, 61, 41-46. [CrossRef]

53. Ravussin, Y.; Koren, O.; Spor, A.; Leduc, C.; Gutman, R.; Stombaugh, J.; Knight, R.; Ley, R.E.; Leibel, R.L. Responses of gut microbiota to diet composition and weight loss in lean and obese mice. Obesity 2012, 20, 738-747. [CrossRef]

54. Warren, Y.A.; Tyrrell, K.L.; Citron, D.M.; Goldstein, E.J.C. Clostridium aldenense sp. nov. and Clostridium citroniae sp. nov. isolated from human clinical infections. J. Clin. Microbiol. 2006, 44, 2416-2422. [CrossRef]

55. Swidsinski, A.; Dörffel, Y.; Loening-Baucke, V.; Theissig, F.; Rückert, J.C.; Ismail, M.; Rau, W.A.; Gaschler, D.; Weizenegger, M.; Kühn, S.; et al. Acute appendicitis is characterised by local invasion with Fusobacterium nucleatum/necrophorum. Gut 2011, 60, 34-40. [CrossRef]

56. Tremaroli, V.; Bäckhed, F. Functional interactions between the gut microbiota and host metabolism. Nature 2012, 489, 242-249. [CrossRef] [PubMed]

57. Xu, Z.; Knight, R. Dietary effects on human gut microbiome diversity. Br. J. Nutr. 2015, 113, 1-5. [CrossRef]

58. Rentas, M.F.; Pedreira, R.S.; Perini, M.P.; Risolia, L.W.; Zafalon, R.V.A.; Alvarenga, I.C.; Vendramini, T.H.A.; Balieiro, J.C.D.C.; Pontieri, C.F.F.; Brunetto, M.A. Galactoligosaccharide and a prebiotic blend improve colonic health and immunity of adult dogs. PLOS ONE 2020, 15, e0238006. [CrossRef]

59. Lin, C.Y.; Carroll, M.Q.; Miller, M.J.; Rabot, R.; Swanson, K.S. Supplementation of Yeast Cell Wall Fraction Tends to Improve Intestinal Health in Adult Dogs Undergoing an Abrupt Diet Transition. Front. Vet. Sci. 2020, 7, 905. [CrossRef] [PubMed]

60. Kubala, L.; Ruzickova, J.; Nickova, K.; Sandula, J.; Ciz, M.; Lojek, A. The effect of $(1 \rightarrow 3)-\beta$-D-glucans, carboxymethylglucan and schizophyllan on human leukocytes in vitro. Carbohydr. Res. 2003, 338, 2835-2840. [CrossRef]

61. Magnani, M.; Castro-Gómez, R.J.H. $\beta$-glucana from Saccharomyces cerevisiae: Constitution, bioactivity and obtaining [ $\beta$-glucana de Saccharomyces cerevisiae: Constituição, bioatividade e obtenção]. Semin. Agrar. 2008, 29, 631-650. [CrossRef] 